\title{
The Issue Of The Ultra Vires Principle In Turkish Company Law: Has It Been Abolished Or Just Hidden?
}

\section{Introduction}

One of the significant codification efforts carried out in Turkish law in the last decade is Turkish Code of Commerce (hereinafter TCC) numbered 6102. ${ }^{1}$ The new TCC entered into force on July 1, 2012, as a result of an 11 year-long effort and as a process step of the European Union candidacy. The new Code specifically referred to the European Union directives in the field of commercial law and aimed to influence commercial law legislation to stay in line with the EU values. One of the innovations in the new TCC was announced as the abandonment of the ultra vires principle by the commission that prepared the draft of the Code. In line with the preferences of the Commission, the legislator has removed the criterion of the field of operation for rights and deeds of commercial companies by the TCC A.135 (Article 135 of the TCC). On the other hand, in the context of the Code, the concept of the company's fields of operation remains valid as a criterion in various provisions. This situation has led to claims that the ultra vires principle has not been abolished, but remains valid and effective, at least by changing its form. In this research, I will try to examine these claims and determine whether the ultra vires principle has been completely repealed.

* Assoc. Prof. Dr., Sakarya University Faculty of Law Commercial Law Department, e-mail: mustafayasan@sakarya.edu.tr, https:/ / orcid.org/0000-0003-0741-9720.

1 Official Gazette, 14 February 2011, No. 27846. 


\section{Ultra Vires Principle and Its Validity in the Repealed TCC}

In the last 30 years, the UK legal system and the continental European system, as well as the Turkish legal system that is a part of it, have become closer thanks to the institutions of the European Union. This rapprochement has been particularly effective in company law. The abolition of the ultra vires principle is a concrete example of the convergence in company law. The abolition of the ultra vires principle first came to the force in the company law of the United Kingdom and subsequently in the continental European legal systems by the European Union directives. ${ }^{2}$ After acquiring the EU candidate country status in the Helsinki Summit in 1999, the necessity and the validity of the ultra vires principle was also questioned in Turkey as a result of this convergence.

The ultra vires principle includes a prohibition that allows commercial companies to conduct business and transactions only within the scope of their business, and prevents them from going beyond the business issues explicitly indicated in their establishment agreements. In the repealed Turkish Code of Commerce numbered 6762, ${ }^{3}$ the principle of ultra vires was accepted as a rule that dominates Turkish company law. As an example, the repealed Code A.137 regulated that the commercial companies were entitled to acquire all rights and debts on condition that they had the legal personality and remain within the circumference of the business subject written in the company contract. ${ }^{4}$

During the period when the ultra vires principle was in effect, the commercial companies' transactions which are other than the business subjects indicated in the company contract and registered in the trade registry

2 L. Sealy, S. Worthington, Sealy's Cases and Materials in Company Law, New York 2010, p. 514; D. Kershaw, Company Law in Context Text and Materials, New York 2009, p. 107; A. Hicks, S.H. Goo, Cases and Materials on Company Law, New York 2008, pp. 168-175.

3 The Repealed Turkish Code of Commerce was enacted in 1956 and came in to force in the beginning of 1957.

4 According to the judgement of the Supreme Court during the former TCC period: "with this regulation (the Repealed Code A.1371 the right to benefit of the commercial companies is limited to the framework of the business subject written in the company contract. According to this theory called «ultra vires» principle, the works outside the business subject of the company will not bind the legal personality of the company." The Assembly of Civil Chambers of the Supreme Court, 29 January 2016. Case No.: 2014/390, Judgement No.: 2016/121, https:/ / karararama.yargitay.gov.tr/YargitayBilgiBankasiIstemciWeb/pf/ sorgula.xhtml [access: 29.05.2020]. 
were not binding on the company. If the commercial companies wanted to make a transaction other than business subjects, firstly the company contract had to be amended. Thus, the ability of the company to qualify and to assume debt was limited to the subject of business written in the company contract. To change the company contract, it was necessary to take decisions at the general assembly with aggravated quorums, and to complete the procedure such as registration in the trade registry and an announcement in the Gazette of Turkish Trade. ${ }^{5}$ All these requirements impeded the ability of commercial companies to operate outside the scope of business subjects and limited the mobility of commercial companies in the senses of both de jure and de facto. For example, for a public limited company engaged in the textile business to do construction work for its factories, the construction subject should have also been mentioned as the subject of operation in the company contract. Unless it was stated in the company contract, the public limited company engaged in textiles had to arrange that another company, whose purpose this was, to carry out the actual construction work. The situation led to both time and material loss. In addition, it could easily facilitate fraudulent and collusive collaboration between commercial companies. Since the legal transactions carried out outside the scope of the business subject was accepted as void or null due to the ultra vires principle, claiming the nullity of the legal transactions after years was used to endanger the transaction security and economic and commercial stability. ${ }^{6}$ Due to the application of the ultra vires principle, commercial companies preferred to explicitly record issues that they would not undertake in company contracts to avoid the restrictive effect of the principle. In practice, this led the commercial companies to write an exaggerated list of the business subjects in the company contracts. ${ }^{7}$

5 B. Yıldız, Ultra Vires İlkesinin Kaldırılmasının Ardından İşletme Konusu Unsuru ve Ticaret Şirketlerinin İşletme Konusu Dışındaki İslemlerinin Hukuki Niteliği, Banka ve Ticaret Hukuku Dergisi 2011, vol. 27, no. 3, pp. 112, 113; S. Hacımahmutoğlu, Anonim Ortaklikta Ultra Vires Doktrini ve Ortakh̆̆̆ Bağlamaya Yetkili Organın (Yönetim Kurulunun) Yetkilerinin Sinirlandirılamaması, Ankara 2016, p. 25.

6 D. French, S. Mayson. C. Ryan, Company Law 2010-2011, New York 2010, p. 605; C. Wild, S. Weinstein, Smith and Keenan's Company Law, Essex 2011, p. 83; L. Sealy, S. Worthington, Sealy's Cases and Materials in Company Law, New York 2010, pp. 610, 611.

7 C. Wild, S. Weinstein, Smith..., p. 130; D. Kershaw, Company Law..., p. 107. 


\section{The New TCC's Approach on the Ultra Vires Principle}

One of the sources that inspired the legislator during the preparation of the TCC is the European Union corporate law legislation. Indeed, the resource related to the ultra vires principle in this legislation is the First Directive of the EEC concerning companies 68/151. ${ }^{8}$ These directives envision the removal of the ultra vires rule from the laws of the member states. ${ }^{9}$ In the directive, it is intended to protect third parties who deal with the company's representatives and trust that these transactions would bind the company. In this way, the fact that the transaction which is made with the representatives of the company is deemed sufficient for the transaction to be valid and to bind the company. However, the legal consequence of this transaction is determined according to whether the third party has good faith or not. ${ }^{10}$

In the general preamble of the TCC, a clear reference was made primarily to the EU legislation. However, in the specific preamble for the TCC A.125, it was stated that the ultra vires principle was abolished by the EU directives. TCC A.125 was rewritten and in the new form of the article, it was regulated that the commercial companies could benefit from the rights and could assume debts within the framework of Turkish Civil Code (hereinafter TCivC) numbered 4721 A.48. ${ }^{11}$ In the preamble, it was also stated that in some provisions of the Code, as in the second paragraph of the TCC A.371, the legal consequences of the transactions performed out of the scope of the business subject are specifically regulated.

TCC A.125 consists of two paragraphs. The first paragraph determines the common characteristics of commercial companies. This characteristic is the existence of the legal personalities of commercial companies. This paragraph of the article is the same as the revealed Code period. However, the second paragraph of the article constitutes the part where the significant change has been made. Accordingly, commercial companies can take

8 A. Hicks, S.H. Goo, Cases and Materials..., p. 123.

9 A. Kendigelen, Türk Ticaret Kanunu Değişiklikler, Yenilikler ve İlk Tespitler, İstanbul 2016, p. 122; M. Bahtiyar, Ortaklıklar Hukuku, İstanbul 2017, p. 49; D. French, S. Mayson, C. Ryan, Company Law 2010-2011..., p. 606.

10 H. Pulaşl1, Şirketler Hukuku Şerhi, Cilt 1, Ankara 2014, pp. 91, 92.

11 Official Gazette, 8 December 2001, No. 24607. 
full advantage of all rights and assume debts under TCivC A.48. ${ }^{12}$ Exceptions in this regard are reserved in the Code. In this way, the limitation of the qualifications of commercial companies regarding the business subject which was valid in the period of the repealed Code, has been removed. ${ }^{13}$ The Company's legal personalities may also qualify and assume debts in matters other than business subjects. On the other hand, the legislator has not accepted full liberty regarding the capacity of legal personalities, because the capacity of legal personalities has been accepted within the framework of TCivC A.48. TCivC A.48 is a provision regulating the legal capacity of legal persons and according to this provision, legal persons are entitled to all rights and debts except those that are dependent on human-specific qualities such as sex, age and kinship. Consequently, although the legal capacity of commercial companies is not limited to business subjects, they do not qualify for human-specific rights and debts due to their legal personalities.

\section{The Issue of whether the Ultra Vires has been Removed by TCC}

\section{A. Business Subject to Limitations of Authority of Company Representatives according to TCC A.371}

The legal regime validated by the TCC A.125 raises the question of whether the ultra vires principle has been completely abolished. As a matter of fact, in addition to this problem, the regulation in the TCC A.125 is misunderstood in practice and interpreted that any legal transaction performed outside the business subject will bind the legal personality of the company as long as it complies with TCivC A.48. These comments are not accurate. The reason for this is that, the legislator also accepted the existence of exceptional cases, in which both private and public limited companies, do not bind the legal personality of the company. The authority of representation of the company's representatives is limited to

12 Ü. Tekinalp, Sermaye Ortaklıklarını Yeni Hukuku, İstanbul 2013, pp. 221, 222; H. Pulaşlı, Şirketler Hukuku Şerhi, Cilt 1..., pp. 91, 92.

13 F. Bilgili, E. Demirkap1, Şirketler Hukuku, Bursa 2013, p. 54; Ü. Tekinalp, Sermaye Ortaklıklarını..., p. 221, 222; M. Bahtiyar, Ortaklıklar..., p. 49. 
the scope and purpose of the company under the TCC A.371, which regulates the authority of representatives in public limited companies and may also be applicable to private limited companies. ${ }^{14}$

According to the TCC A.371, those authorized to represent the public limited company may carry out all kinds of works and legal transactions that fall within the scope and purpose of the company, and may use the title of the company on behalf of the company. ${ }^{15}$ On the other hand, the legal consequence of the transactions performed by those authorized to represent the company outside the business subject is not invalidity. ${ }^{16}$ In actuality the rule is that the authorized persons who represent the company also can also make transactions with third parties outside the business subject. This is a rule, but there are exceptions. In other words, if a legal transaction is carried out as other than within the business subject, there is a possibility that this transaction does not bind the company, as indicated by the lawmaker. ${ }^{17}$ Accordingly, if the third party, who is a party to the transaction exceeding the limits of the authorization knows that the transaction is outside the scope of the operation, or due to the situation may know about it, the legal personality of the company is relieved of being bound by the legal transaction performed outside the scope of the business subject. ${ }^{18}$ The company's legal personality must prove that the conditions for the realization of the exception are met. The issues required for proof should be considered separately in each concrete case. On the other hand, the fact that the articles of association of the company have been announced and the fact that the subject of operation is shown in the announced company agreement is not sufficient to realize the exception alone. ${ }^{19}$ In cases where the legal personality of the company cannot prove that the third party is not a bona fide person, it is bound by the legal transaction that has been performed by exceeding the authority of representation in accordance

14 Ş. Yıldız, Limited Şirketler Hukuku, İstanbul 2007, pp. 260, 261.

15 E. Moroğlu, 6102 Sayılı Türk Ticaret Kanunu, Değerlendirme ve Öneriler, İstanbul 2012, p. 168; G. Üçışı, A. Çelik, Anonim Ortaklıklar Hukuku, Cilt 1, Ankara 2013, p. 456.

16 A. Kendigelen, Türk Ticaret..., p. 122; G. Üçışık, A. Çelik, Anonim..., p. 456; Ş. Yıldız, Limited Sirketler..., p. 260, 262; S. Hacımahmutoğlu, Anonim Ortaklıkta..., p. 120.

17 O.H. Şener, Teorik ve Uygulamalı Ortaklıklar Hukuku, Ders Kitabı, Ankara 2017, p. 378; F. Bilgili, E. Demirkapı, Şirketler Hukuku..., pp. 53, 54; B. Yıldı, Ultra Vires..., p. 117-120.

18 D. Kershaw, Company Law..., p. 370; E. Moroğlu, 6102 Sayılı..., p. 168; M. Bahtiyar, Ortakliklar..., p. 232.

19 O.H. Şener, Teorik..., pp 376, 377; B. Yıldız, Ultra Vires..., pp. 117-120. 
with the rule. However, the legal personality of the company may have recourse against the person who exceeds the authority of representation even if it is bound by this transaction. Thus, even if the transaction which is made binds the company as a rule, in case of a loss, the shareholders of the company will be able to take recourse against the company representatives who exceed the limits of the representation authority due to the loss incurred, with the will of the general assembly. The company may limit the authority of the representatives within the scope of the business subject. However, this limitation cannot be applied against the bona fide third parties. To accept the limitations for the third parties, the existence of the mala fide must be proved at first. ${ }^{20}$ It may not be registered in the trade registry, where the powers of the representatives are limited within the scope of the enterprise, and even if registered, this registration shall not be valid for third parties. Therefore, the existence of third parties' malice must be proved by other convincing evidence. ${ }^{21}$

\section{B. Other Legal Consequences of the Concept of Field of Operation in the TCC}

In the TCC, the provisions linking the legal result to the subject of business of the legal personality of the company are not only composed of the TCC A.371. It is seen that the concept of business subject is used in 25 articles which are scattered in a non-systematic way in the TCC consisting of 1535 articles. On the other hand, another point that draws attention in the TCC is that the legislator has included the concept of the subject of the company as well as the business subject. In the collective and limited partnership companies, the concept of company subject is preferred instead of the concept of the business subject. In the TCC A.311, while prohibiting competition in limited partnership companies, both concepts of the business subject and the company subject are used in the same article and even in the same paragraph. This is a definite mistake in terms of the law-making technique. To eliminate this failure and ensure the unity of the term, I suggest that only the concept of the business subject should be preferred by the legislator.

20 A. Kendigelen, Türk Ticaret..., p. 122; F. Bilgili, E. Demirkapı, Şirketler Hukuku..., p. 54; S. Hacımahmutoğlu, Anonim Ortaklikta..., p. 115.

${ }^{21}$ E. Moroğlu, 6102 Sayılı..., p. 168. 
Under this heading of our study, we will focus on some of the provisions in the TCC where the criterion of the business subject is still effective. We will examine the conclusions to which the legislator binds the concept of the business subject. In this way, we will see that the business subject and its derivatives in the TCC are not abandoned completely by the legislator and they remain valid only by changing form.

1. Trade names of capital companies and cooperatives are regulated in the TCC A.43. In the core part of the trade names of these companies, the business subjects of the companies should be shown before the statement indicating the company and its type. Otherwise, trade names are invalid.

2. In the TCC A.151, the issue of taking a merger decision in commercial companies is regulated. According to the TCC A.151, if the merger agreement provides for a change in the business subject of the transferred company, the merger agreement must also be approved with the required quorum for the amendment of the company agreement.

3. The regulation and supervision authority of the Ministry of Trade is regulated in Article 210. According to the TCC A.210 para. 3, the Ministry of Trade may file a lawsuit for termination of commercial companies determined to carry out transactions or preparations in this direction or to engage in collusive works and activities. The Ministry of Trade is required to file a case for termination within one year of getting informed of such transactions, preparations or activities.

4. Mandatory records of collective company contracts are regulated in the TCC A.213. Accordingly, the business subject of the company should be defined completely.

5. The scope of management in collective companies is regulated in the TCC A.223. Accordingly, matters within the scope of the management of the company are limited to the ordinary causal transactions and work to be performed to obtain the purpose and subject of the company. The directors of the company are also authorized to settle, waive, accept and arbitrate, provided that they are limited to the ordinary transactions and works, in the works they deem appropriate for the benefit of the company. The Court of Appeal (Yargitay, the Supreme Court) has also adjudged that a contract other than the subject of operation made by the representatives in collective companies is subject to nullity sanction. ${ }^{22}$

22 The 19th Civil Chamber of the SuSreme Court, 29 May 2018, Case No.: 2017/5518, Judgement No.: 2018/3038, https:/ / karararama.yargitay.gov.tr/YargitayBilgiBankasiIstemciWeb/ [access: 29.05.2020]. 
This decision may prove that the principle of ultra vires is still valid in the concept of limitations of representatives' authorities in collective companies.

6. TCC A.233 regulates the representation of collective companies. Under this provision, the person authorized to represent the collective company has the authority to carry out all kinds of business and legal transactions on behalf of the company and to use the title of the company, as long as these transactions can be related to the business subject of the company.

7. In the TCC A.245, the existence of justified reasons among the reasons for dissolution in collective companies is regulated. The justified reason is that the actual or personal reasons leading to the establishment of the company have ceased to exist in such a way as to make it impossible or difficult to obtain the business subject of the company.

8. TCC A.292 regulates the powers of liquidators in collective companies. These powers include transactions within the scope of the company's business. Accordingly, the liquidators are allowed to carry out transactions within the scope of the company's business subject only by a unanimous vote of the shareholders.

9. In the TCC A.311, a prohibition of competition in limited partnership companies is regulated. In collective companies, partners cannot carry out the same transactions that constitute the subject of the company. This provision applies only to commandite partners in limited partnerships. It is further regulated that, if the commanditaires set up a commercial enterprise to deal with the works that fall within the scope of the company's business, or if it becomes a partner with such a person or enters a company of this nature, the commanditaire partner loses the right to examine its documents and records.

10. TCC A.333 regulates the supervision of the state over public limited companies. Accordingly, the state, provincial special administration, municipality, village and one of the other public legal personalities shall have the right to appoint representatives to the boards of directors in public limited companies, even if they are not shareholders, with a provision stipulated in the articles of association. For this purpose, the business subject of public limited companies must be related to public service.

11. The compulsory contents of the articles of association of public limited companies are listed in the TCC A.339. One of these content elements is the business subject of the company. The articles of association of 
the company must indicate the business subject of the company in a way that the essential points are completely defined.

12. The duties and powers of the public limited companies' board of directors are regulated in the TCC A.374. Accordingly, the board of directors is authorized to make decisions on all kinds of works and transactions necessary for the realization of the business subject of the company, except those left under the authority of the general assembly in accordance with the Code and the articles of association.

13. In the TCC A.396, the prohibition of competition to which the members of the board of directors are subject is regulated. Accordingly, the members of the board of directors may not carry out any transactions within the scope of the company's business subject without the permission or approval of the general assembly. ${ }^{23} \mathrm{~A}$ member of the board of directors cannot enter into a company dealing with the same kind of business subject as an unlimited liable partner.

14. In the TCC A.421, the meeting and decision quorums for the amendments on the articles of association are regulated. One of these quorums involves the existence of affirmative votes of the owners or representatives of the shares which constitute at least seventy-five percent of the capital. The amendment of the articles of association, which requires this aggravated quorum, relates to the complete change of the business subject of the company.

15. In the TCC A.576, the mandatory content of the company contracts in private limited companies are determined. One of these mandatory content elements is the business subject of the company in a manner defined in parallel to the public limited companies. In the TCC A.587, the subject of the business of the company is shown as one of the issues to be registered in the trade registry. The company's business subject is one of the issues in which the trade registry can perform a positive impact.

16. In the TCC A.606, an additional performance obligation is regulated. Accordingly, in private limited companies, the company's contract

${ }^{23}$ For the audgement of the Supreme Court referring ultra vires principle as condition sor the limits of the prohibition of the competition see: the 11th Civil Chamber of the Supreme Court, 24 February 2014, Case No.: 2013/14242, Judgement No.: 2014/3337, https://karararama.yargitay.gov.tr/YargitayBilgiBankasiIstemciWeb/pf/sorgula.xhtml [access: 29.05.2020]. 
may provide for additional subsidiary performance obligations that may serve the realization of the business subject.

17. In the TCC A.621, the quorum rules governing the important decisions to be taken in the general assembly of the private limited companies are included. This quorum is a combination of at least two-thirds of the votes represented and the absolute majority of the total capital holders which are entitled to vote. One of the important decisions that require such aggravated quorum relates to the modification of the company's subject of business.

\section{The Approach of the Supreme Court}

It must be admitted that there are contradictions in the decisions of the Supreme Court related to ultra vires position in the TCC. In some cases, the Supreme Court accepts that the principle of ultra vires has been abolished in all commercial companies while in some cases the Supreme Court refers to the validity of the ultra vires principle in collective companies. The Supreme Court bases the limits of the collective company's representatives' powers and the bindingness of the transaction to the ultra vires principle.

In order to see the contradiction of the Supreme Court's judgements, it is appropriate to give some examples of this inconsistency. The Supreme Court adopted that the ultra vires principle was completely abolished by the TCC numbered 6102 according to an judgement dated 2017. In this court decision, the activities of commercial companies were limited to the subject of the business written in the contract of the company as a result of the ultra vires rule in the revealed commercial code numbered 6762. Thanks to the TCC A.125 and 371, the ultra vires principle was abolished in terms of all commercial companies. The Supreme Court underlined that even if a company does not have a license to run a construction work, it is not forbidden to be engaged in the construction business. For example, a commercial company established in the field of textiles can also perform construction work ${ }^{24}$. On the other hand, the Supreme Court also adjudged

24 The10th Civil Chamber of the Supreme Court, 18 October 2017, Case No. 2015/19350, Judgement No.: 2017/7017, https:// karararama.yargitay.gov.tr/YargitayBilgiBankasi 
that a contract other than the subject of operation made by the representatives in collective companies, is subject to nullity sanction ${ }^{25}$. This decision acknowledges that for collective companies the principle of ultra vires, still retains a rule that affects the validity of contracts made on behalf of the company legal personality.

\section{Review and Evaluation}

One of the most pretentious provisions in the TCC which claims to realize the innovations in the sense of reform in the field of company law is TCC A.125, which is interpreted as abandoning the ultra vires principle. As a matter of fact, in the preamble of the Code, the legislator states that thanks to the TCC A.125, the ultra vires principle is not included in the new company law regime in order to ensure compliance with EU law system. As a result of this approach, the criterion of the subject of the business has been abandoned in order to determine the limit of the rights of the commercial companies and especially the capital companies.

By the TCC A.125, it has become possible for the company's legal personality to qualify and assume debt on matters other than the business subject. On the other hand, it is assumed that the legislator does not completely abandon the concept of the business subject while regulating the scope of representation powers of public limited companies' and private limited companies' representatives, and the legal consequences that may arise when this scope is excluded. For the limits of the representative powers of the company's representatives, the business subject criteria of the company have been adopted. As a rule, even if this authorization is

IstemciWeb/pf/sorgula.xhtml [access: 29.05.2020]. For other smilar judgements see: the 10th Civil Chamber of the Supreme Court, 19 January 2016, Case No.: 2015/19632, Judgement No.: 2016/287. 19 January 2016, Case No. 2015/19632, Judgement No. 2016/287, https:/ / karararama.yargitay.gov.tr/YargitayBilgiBankasiIstemciWeb/pf/sorgula.xhtml) [access: 29.05.2020]; The 10th Civil Chamber of the Supreme Court, 26 October 2015, Case No.: 2015/12626, Judgement No.: 2015/17712, https://karararama.yargitay.gov.tr/YargitayBilgiBankasiIstemciWeb/pf/sorgula.xhtml) [access: 29.05.2020].

25 The 19th Civil Chamber of the Supreme Court, 29 May 2018, Case No.: 2017/5518, Judgement No.: 2018/303, https:/ / karararama.yargitay.gov.tr/YargitayBilgiBankasiIstemciWeb/ [access: 29 May 2020]. 
exceeded, legal proceedings shall be binding on the legal personality of the company.

Besides, the concept of the business has had a decisive influence throughout the legal regime of commercial companies, including the trade names of capital companies. In the light of all these statements, the existence of perplexity regarding the abandonment of the ultra vires principle in the TCC, which still gives a decisive role to the company's business subject, is very common. The improper attitude of the legislator, which raises doubts in this approach, is frequently encountered in other institutions in the TCC. Stability in the TCC has not been ensured in the supervision of capital companies, even with the obligation to establish a web page and the fulfilment of the capital setting debt. In the TCC, conflicting provisions are included concerning the articles that may be put into the company's agreement.

Another reflection of this inaccurate and unsuccessful codification effort is the existence of doubts raised by the legislator about whether the ultra vires principle has been abolished. The legislator did not establish the connection between the preamble and the articles of the provisions. While the starting point of the Code was the intention to establish a codification completely compliant with the EU law, the point which has been reached is far from this aim. Unfortunately, similar contradictions can be noticed in many articles of the Code. In our opinion, the perception that "the ultra vires principle has been abandoned or terminated" caused by the legislator's approach does not reflect the truth. Instead of this false perception, it would be more accurate to state that the ultra vires principle still makes its presence noticeable in the TCC and that it indeed is included in the TCC however under its changed form.

\section{Conclusion}

Has the ultra vires principle been abolished following the norms of the European Union, or have the Turkish lawmakers recognized the validity of the ultra vires principle in spite of everything? It is not possible to give a clear and easy answer to this question in the light of our explanations above, despite the ambitious explanations in the preamble of the Turkish Code of Commerce. 
Despite contradictory judgements of the Supreme Court, it is certain that the criterion of the business subject is no longer valid in determining the limits of the legal capacity of the company's legal personality. However, the legislator has not completely abandoned the criterion of the business subject. As mentioned before, in more than 20 articles in the TCC, the concept of the business subject is accepted as a defining criterion and supposition. For this reason, it is seen that the legislator remains in a dilemma despite the justification. This dilemma is only one of the contradictions and inconsistencies that we have to face throughout the TCC. Therefore, it is not possible to state that the ultra vires principle has lost its validity, in spite of the justification in the preamble of the Code and that it has been completely deleted from the systemic of the TCC. In our opinion, it will be the most accurate interpretation to accept that the principle of ultra vires is still valid by changing shape and format.

\section{Bibliography}

Bahtiyar M., Ortaklıklar Hukuku, İstanbul 2017.

Bilgili F., Demirkapı E., Şirketler Hukuku, Bursa 2013.

French D., Mayson S., Ryan C., Company Law, 2010-2011, New York 2010.

Hacımahmutoğlu S., Anonim Ortaklıkta Ultra Vires Doktrini ve Ortaklğ̆ Bağlamaya Yetkili Organın (Yönetim Kurulunun) Yetkilerinin Sinırlandırlamaması, Ankara 2016.

Hicks A., Goo S.H., Cases and Materials on Company Law, New York 2008.

Kendigelen A., Türk Ticaret Kanunu Değişiklikler, Yenilikler ve İlk Tespitler, İstanbul 2016. Kershaw D., Company Law in Context Text and Materials, New York 2009.

Moroğlu, E., 6102 Sayılı Türk Ticaret Kanunu, Değerlendirme ve Öneriler, İstanbul 2012.

Pulaşlı H., Şirketler Hukuku Şerhi, Cilt 1, Ankara 2014.

Sealy L., Worthington S., Sealy's Cases and Materials in Company Law, New York 2010. Şener O.H., Teorik ve Uygulamalı Ortakliklar Hukuku, Ders Kitabı, Ankara 2017.

Tekinalp Ü., Sermaye Ortakliklarmmn Yeni Hukuku, İstanbul 2013.

Üçışık G., Çelik A., Anonim Ortaklıklar Hukuku, Cilt 1, Ankara 2013.

Wild C., Weinstein S., Smith and Keenan's Company Law, Essex 2011.

Yıldız B., Ultra Vires İlkesinin Kaldırlmasının Ardından İşletme Konusu Unsuru ve

Ticaret Şirketlerinin İşletme Konusu Dışındaki İşlemlerinin Hukuki Niteliği, Banka ve Ticaret Hukuku Dergisi 2011, vol. 27, no. 3.

Yıldız Ş., Limited Şirketler Hukuku, İstanbul 2007. 


\section{Su m m a ry}

The Turkish Code of Commerce (TCC) numbered 6102 contains numerous radical regulations as reforms in the Turkish company law. One of these provisions is the TCC A.125 which regulates the capacity of commercial companies to have rights and obligations. This article deals with the ultra vires principle which was transferred to the Continental European law system, including the Turkish legislation from the UK law system. The ultra vires principle had previously expired in the continental European legal system (in particular the Swiss Code of Obligations) which has inspired the TCC as a referring codification. As a result of these developments by the TCC A.125, in contrast to the ultra vires principle, commercial companies are allowed to be entitled and liable for all kinds of matters, except those which are human-specific. For this reason, companies' legal personalities may have the capacity to have rights and obligations in matters other than their fields of operation. In other words, thanks to the TCC A.135, the ultra vires principle has been abandoned. It can be assumed that harmonization between the TCC and the EU directives has been achieved in the sense of abolishing the ultra vires principle. However, when several provisions randomly scattered in the TCC are taken into consideration, it is obviously seen that the legislator still accepts the field of operation issue as a criterion in about 20 articles. This leads to a question about the actual abolishment of the ultra vires principle. To put it briefly, the legislator's choice in the new company law regime shows that the TCC has not abandoned the ultra vires principle completely, but it still retains its validity in a hidden way by only changing its form and scope.

Key words: Ultra vires principle, Turkish Code of Commerce, Turkish Company Law, Capacity to have rights and obligations, Commercial companies

\section{STOSOWANIE ZASADY ULTRA VIRES W TURECKIM PRAWIE SPÓŁEK: WYŁĄCZONE CZY UKRYTE?}

\section{Streszczenie}

Turecki kodeks handlowy (TCC) oznaczony numerem 6102 zawiera szereg radykalnych rozwiązań przewidzianych jako reformy tureckiego prawa spółek. Jednym z takich przepisów jest art. 125 TCC, który odnosi się do zdolności prawnej spółek handlowych. Artykuł ten porusza kwestię zasady ultra vires, która została inkorporowana do europejskiego kontynentalnego systemu prawnego, włączając turecki system prawny z porządku prawnego Zjednoczonego Królestwa. Jednakże zasada ta z czasem została uznana za wygasłą w ramach europejskiego kontynentalnego systemu prawnego (w szczególności w szwajcarskim kodeksie 
zobowiązań), co z kolei zainspirowało ustawodawcę tureckiego do zmian w kodyfikacji. Wynikiem tych działań, na podstawie art. 125 TCC, sprzecznie z zasadą ultra vires, spółki handlowe mają zdolność do bycia podmiotem praw i obowiązków w szerokim zakresie, z wyłączeniem kwestii zarezerwowanych wyłącznie dla osób fizycznych. Z tego powodu w ramach osobowości prawnej przedsiębiorstw mogą one być uzdolnione do bycia podmiotem praw i obowiązków w sprawach wykraczających poza ich własny zakres działalności. Innymi słowy, za sprawą art. 125 TCC koncepcja stosowania zasady ultra vires została porzucona. Można zatem dojść do konkluzji, że dostosowanie TCC do dyrektyw Unii Europejskiej w kwestii zniesienia zasady ultra vires zostało osiągnięte. Jednak biorąc pod uwagę szereg przepisów z różnych części Kodeksu, widoczne staje się, że ustawodawca wciąż uznaje przesłankę zakresu prowadzonej działalności jako warunek w ok. 20 przepisach prawnych. To z kolei prowadzi do pytania o rzeczywiste wyłączenie zasady ultra vires. Konkludując, należy stwierdzić, że wprowadzony przez ustawodawcę nowy reżim prawa handlowego jasno wskazuje, że Kodeks handlowy nie wyłączył zasady ultra vires w całości, a utrzymując jej stosowanie w sposób ukryty, jedynie zmienił jej zakres.

Słowa kluczowe: zasada ultra vires, turecki kodeks handlowy, tureckie prawo spółek, zdolność prawna, spółki handlowe

\section{ПРИМЕНЕНИЕ ПРИНЦИПА ULTRA VIRES В ТУРЕЦКОМ ЗАКОНОДАТЕЛЬСТВЕ О КОМПАНИЯХ: ИСКЛЮЧЕНО ИЛИ СКРЫТО?}

\section{Резюме}

Турецкий Коммерческий Кодекс (ТКК) номер 6102 содержит ряд радикальных решений, предусмотренных в качестве реформ законодательства о компаниях Турции. Одно из таких положений - ст. 125 ТКК касается правоспособности коммерческих компаний. В настоящей статье рассматривается вопрос о принципе ultra vires, который был включен в европейскую континентальную правовую систему, включая правовую систему Турции в правовой порядок Великобритании. Однако со временем было объявлено, что срок действия этого правила истек в соответствии с правовой системой континентальной Европы (в частности, Швейцарским кодексом обязательств), что, в свою очередь, побудило турецких законодателей внести поправки в кодификацию. В результате этих действий в соответствии со ст. 125 ТКК, вопреки принципу ultra vires, коммерческие компании могут быть подвержены широкому спектру прав и обязанностей, за исключением вопросов, закрепленных только за физическими лицами. По этой причине 
в рамках правосубъектности предприятий они могут обладать правами и обязанностями в вопросах, выходящих за рамки их собственной деятельности. Другими словами, благодаря ст. 125 ТКК, концепция применения принципа ultra vires была оставлена. Таким образом, можно сделать вывод о приведении Коммерческого кодекса Турции в соответствие с директивами Европейского Союза, касающимися отмены принципа ultra vires. Однако, принимая во внимание ряд положений из различных частей кодекса, становится очевидным, что законодатель по-прежнему признает условие объема осуществляемой деятельности обязательным условием примерно в 20 правовых положениях. Это, в свою очередь, поднимает вопрос о том, как на самом деле исключен принцип ultra vires. В заключение следует отметить, что новый режим коммерческого права, введенный законодателем, четко указывает на то, что Коммерческий кодекс не исключил принцип ultra vires в целом, а, сохранив его скрытым образом, лишь изменил сферу его применения.

Ключевые слова: принцип ultra vires, Турецкий Коммерческий Кодекс, турецкий закон о компаниях, правоспособность, коммерческие компании 
